\title{
Effects of the administration of aqueous extract of de Sedum dendroideum on the histopathology of erosive induced gastritis by means of indomethacin in rats ${ }^{1}$
}

\author{
Nilo César do Vale BarachoI, Rafaela Vazi Ribeiro" ${ }^{\text {II }}$, Renato Maduro Pereira ${ }^{\mathrm{II}}$, Roseane de Souza Cândido Irulegui ${ }^{\mathrm{II}}$ \\ IPhD, Health Sciences. Full Professor, Pharmacology and Biochemistry, Medical School of Itajuba (FMIt), Itajuba-MG, Brazil. Conception, design, \\ scientific and intellectual content of the study; acquisition and interpretation of data; critical revision; final approval.

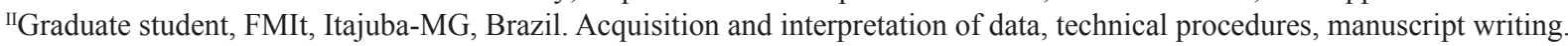

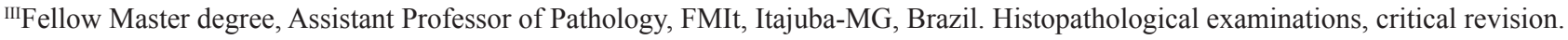

Text

\begin{abstract}
PURPOSE: To evaluate the effects of acute administration of Sedum dendroideum on the gastric histopathology of rats after the administration of indomethacin.

METHODS: Twenty four Wistar rats were randomized into three groups, submitted to feeding privation for 24 hours prior to the oral administration of $50 \mathrm{mg} / \mathrm{Kg}$ of indomethacin and during the experimental period of six hours. The control group (C) was giving distilled water, the extract group (E) was treated with the extract of Sedum dendroideum and the group Omeoprazole (O) received $20 \mathrm{mg} / \mathrm{Kg}$ of omeoprazole. All the treatments were carried out thirty minutes prior to the administration of indomethacin. After six hour, the stomach of the animals was extirpated for histopathological analysis, which took into account the presence of erosive gastritis, hyperemia and sub mucosa edema.
\end{abstract}

RESULTS: In group C, eight out of eight animals presented that type of lesion, in group E, this number was the same and in group O, three out of the eight rats presented erosive gastritis.

CONCLUSION: Sedum dendroideum extract did not produce reduction in the erosive gastritis process. As expected, the treatment with omeoprazole produced a major reduction, when compared with the control group.

Key words: Phytotherapy. Histology. Gastritis. Indomethacin. Rats. 


\section{Introduction}

The gastrointestinal ulcerous lesions are the result of the digestion of the mucosa by peptic acid secretion that occurs when there is a rupture of the equilibrium among the defense of the mucosa and the aggressive action of the gastric succus ${ }^{1}$.

The disease is associated with two major factors: infection by Helicobacter pylori and the use of non-steroidal anti-inflammatory medicine. Today, it is believed that $90 \%$ of the ulcers are due to the infection by Helicobacter pylori (HP), which attacks half of the world population. The bacterium, which is chlorine acid resistant, is able to penetrate the mucosa barrier and liberate digestive enzymes that make the mucosa to liquefy, besides increasing the secretion of gastrin by the inhibition of the production of somatostatin. In the case of non steroidal antiinflammatory medicine (AINEs), such as the indomethacin, it is probable that the ulcers are developed as a consequence of the direct toxic effect and systemic by means of the weakening of the defense mechanisms by means of inhibition of the cicloxigenase (mainly COX-1), key enzyme for the synthesis of the prostaglandins, that protect to gastric mucosa by means of their stimulating effects on the production of mucus and secretion of bicarbonate, while they increase mucosal blood flux and reduce cellular turnover ${ }^{2,3}$.

The advance in the current clinical therapeutics include the introduction of antagonists of receptors H2, proton bomb inhibitors, therapies for the eradication of the Helicobacter pylori and endoscopic approaches for the treatment of hemorrhagic ulcers. In this context, the incidence or elective surgeries for the treatment of the peptic ulcerous disease has declined, yet being advised in cases of relapses or complications ${ }^{4}$.

Gastro duodenal ulcers still are the most common diseases in the digestive tract, they constitute serious medical problems, raising elevated economical costs for the country. Better therapeutic results are being expected as treatment resources are simpler, well-tolerated and of easy adherence by the patients and of low $\operatorname{cost}^{5}$.

In recent publications, the usefulness of medicinal plants for the treatment of gastric disorders has been tested. The phitotherapy is an old and common practice, which is increasing during the last years. About $80 \%$ of the world population uses resource from popular medicine, although be not able to justify its effectivess, which emphasizes the scientific importance of the study and improvement of such practice ${ }^{6}$.

Within this context, Sedum dendroideum Moc. et Sessé ex DC, Crassulaceae, belonging to the order Saxifrage, is a perennial, succulent, sub ligneous and xerophytic plant, originally from
South Africa, of dry tropical climate. In Brazil, it is amply adapted, growing spontaneously and it is popularly named "balsam". Nonetheless, the empiric popular knowledge existing about its probable medicinal effects for the protective gastrointestinal action, used for fighting against inflammations or even for peptic ulcers, there is a very limited evaluation on literature regarding these vegetable properties, which leads to the research for the development of new studies about this plant, aiming the scientific confirmation of its therapeutic properties?

\section{Methods}

This study has been approved by the Committee for Ethics in Research and by the Commission for the Ethical Use of Animals at Medicine School of Itajuba-MG, where it was developed under number 06/13, according to the Federal Law 11.974 and Decree 6.689 , besides guidelines according to the Brazilian College of Animal Experimentation (COBEA).

For the conduction of the experiment, 24 male adult and young Wistar rats, with weight ranging 200 to $250 \mathrm{~g}$ and 60 to 90 days old were used. The animals were kept in plastic cages, were given water and food ad libitumand during the feasting period were kept in cages with screened bottom, and were submitted to dark/light period of 12 hours $^{8,9}$.

\section{Preparation of the Sedum dendroideum extract Moc. et Sessé ex DC}

Samples of Sedum dendroideum obtained at the herbarium of Federal University of Lavras (UFLA), MG, Brazil, where they have been identified, were catalogued at College of Teaching and Research of Itajuba (FEPI) by the agronomist Liliana Auxiliadora Avelar Pereira Pasin, under number Cr 102/ Fepi 2012, and afterwards planted and grown in garden beds at Medical School of Itajuba (FMIt), MG, Brazil, and harvested in February 2011.

The aqueous extract of Sedum dendroideum was prepared after maceration of $100 \mathrm{~g}$ of balsam leaves, freshly collected, without addition of any ingredient. The extracted obtained was filtered in paper filter and the liquid was stored in amber containers ${ }^{10}$.

\section{Induction of erosive gastritis by means of indomethacin}

The animals were submitted to alimental privation for a period of 24 hours. After that period, all of them orally (gavage) received $50 \mathrm{mg} / \mathrm{kg}$ of indomethacin in a unique dose ${ }^{11}$. 
The animals were randomized in three groups of eight rats $(n=8)$. Those animals received the treatments described below, in a unique dose, by means of gavage, in the morning, thirty minutes after the administration of indomethacin ${ }^{8,9}$.

- Group C (control) - distilled water $(\mathrm{n}=8)$

- Group E (extract) - $13 \mathrm{ml} / \mathrm{kg}$ of Sedum dendroideum extract $(\mathrm{n}=8)^{10}$

- Group O (omeoprazole) $-20 \mathrm{mg} / \mathrm{kg}$ of omeoprazole $(n=8)^{11}$

Six hours after the referred treatments the animals were euthanized with an overdose of ketamine/xilazine, and then were placed in corked gutter. After that the ventral portion of the abdomen was incised for the extirpation of the stomach ${ }^{11,12}$.

\section{Histopathological analysis}

The stomachs were open along the great curvature and had their mucosa delicately washed in physiologic solution and were distended with aid of pins on the corked gutter, for observation and photography.
Then the tissues were fixed in a formalin solution (4\%). After the fixation and obtaining the slides, they were dehydrated in absolute alcohol, xylene diaphysectomied, embedded and paraffin included (melt at $56^{\circ} \mathrm{C}$ ). Finally, they were dyed with hematoxylin-eosin and Masson's Trichrom.

The parameters used for the histopathology of the tissues were mainly the presence of: erosive gastritis, hyperemia and sub mucosa edema.

\section{Results}

By means of macro and microscopic analyses of the extirpated stomachs, it was possible to observe the presence of hyperemia and erosive gastritis in eight (100\%) of the animals from the control group. In the group extract, the same alterations were found in all the components of that group. In the omeoprazole group, from the total of eight animals that were analyzed, besides some degree of hyperemia and sub mucosa edema, only three $(37.5 \%)$ presented foci of erosive gastritis (Table 1)

TABLE $1-(+)$ = hyperemia and low intensity edema; $(++)$ hyperemia moderate edema; $(+++)=$ hyperemia and severe edemas.

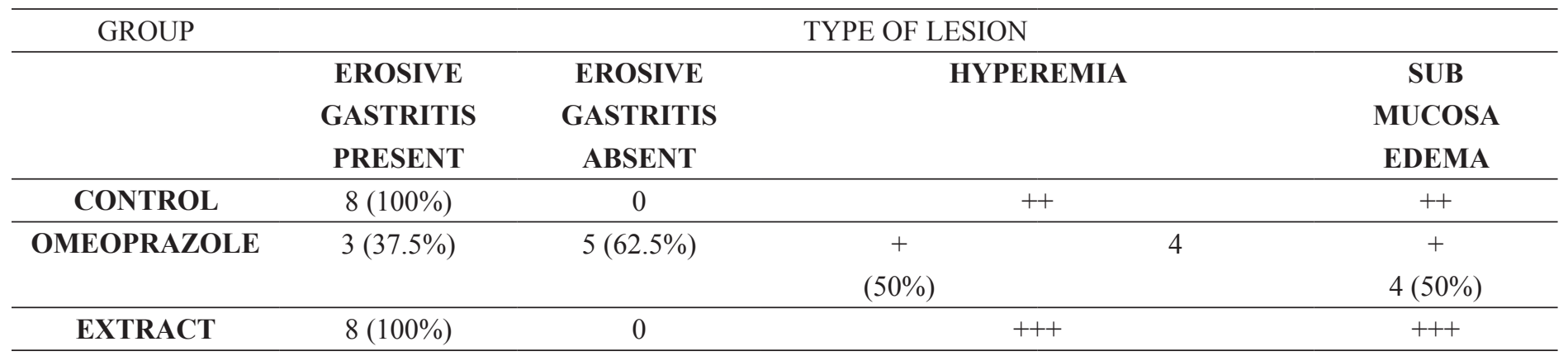

In the control group, many foci of erosive gastritis were found, both macro and microscopically. Besides that, it was possible to percept hemorrhagic areas, and, on the optical microscope, hyperemia and sub mucosa edema (Figure 1).
In the majority of the rats from the group omeoprazole, foci of erosive gastritis were found and the regions of mucosa and sub mucosa were intact, with absence of hyperemia, hemorrhage or edema (Figure 2).
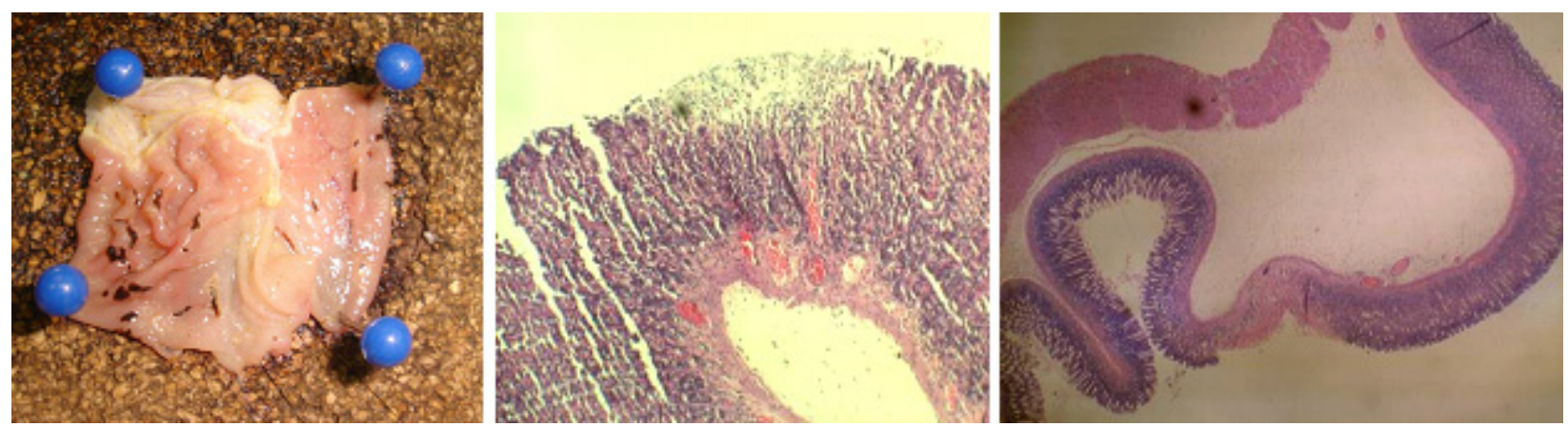

FIGURE 1 - Hemorrhagic areas, and, on the optical microscope, hyperemia and sub mucosa edema. 


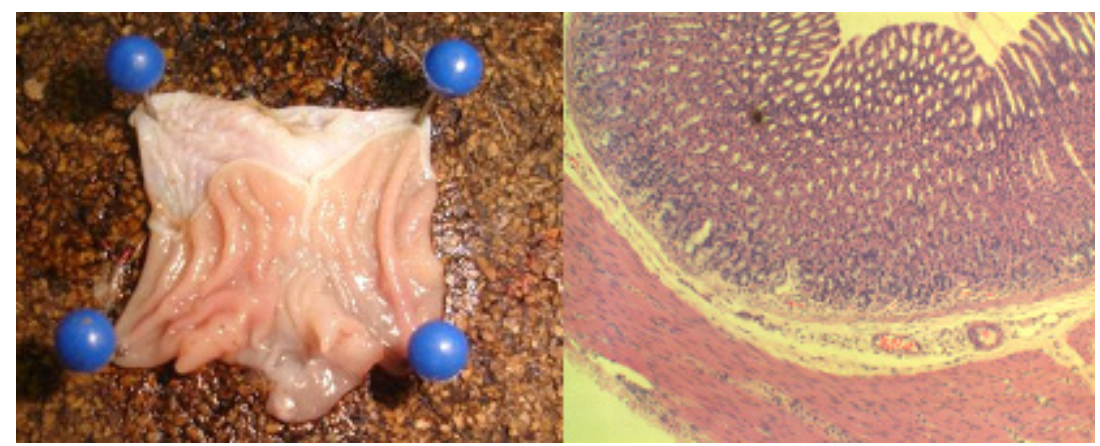

FIGURE 2 - Absence of foci of erosive gastritis, hyperemia, hemorrhage or edema on the regions of mucosa and sub mucosa.

Even if some foci of gastritis were present in three of the eight animals belonging to this group, the foci were less intense, that is, qualitatively inferior to the ones found in the control group, having only a slight hyperemia and sub mucosa edema in a minor extension (Figure 3).
In the extract group, foci of erosive gastritis, hemorrhage, hyperemia and sub mucosa edema were found, but it was possible to notice a major severity in the lesions that were present, that were characterized by a greater extension, going into deeper regions of the mucosa, and also more cellular activity (Figure 4).
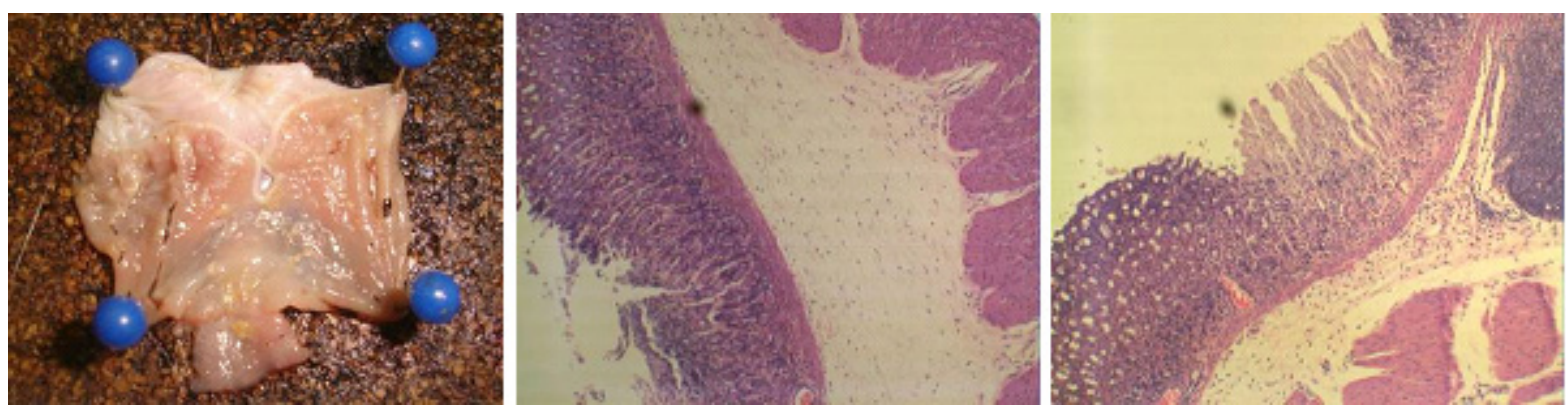

FIGURE 3 - As seen on this photo, it is noticeable the presence of a slight hyperemia and sub mucosa edema in a minor extension.
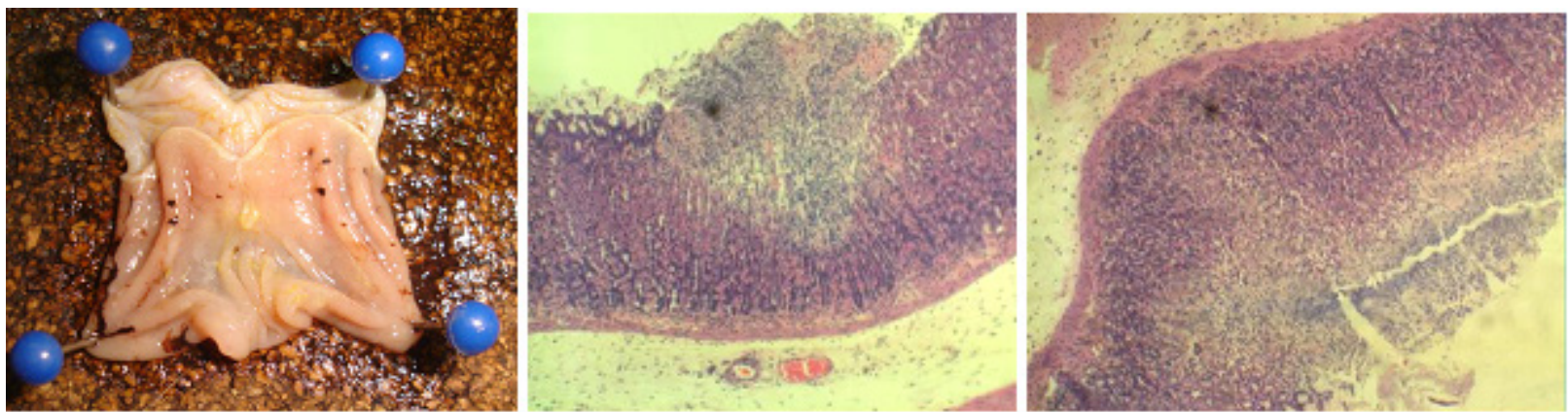

FIGURE 4 - The photos show foci of erosive gastritis, hemorrhage, hyperemia and sub mucosa edema, yet of major severity and extension, going into deeper regions of the mucosa and presenting major cellular activity.

\section{Discussion}

For the last few years, some plants, such as Maytenus ilicifolia Planch., Croton cajucara Benth., Turnera ulmifiolia L., Quassia amara L., Bryophyllum calycinum Salisb., Brassica oleracea L. e Astronium urundeuva. have been studied with the aim of having their possible antiulcerogenic effects determined. Nonetheless, a little is known about the Sedum dendroideum, mainly about its gastric protective properties, although it is largely used by the population ${ }^{13}$.

The macro and microscopic findings in the gastric tissues of the animals in this experiment made it possible to conclude that the method used to induce acute gastritis was satisfactory. Although the existence of other well-known methodologies as the administration of ethanol, chlorydric acid or even stress due to cold, the oral administration of indomethacin showed to have a 
major ulcerogenic potential due to the inhibition of COX-1 and, consequently, of the prostaglandin synthesis. Many studies report the increase in the gastric acid secretion, mucosa alterations and gastric motility with the use of this drug ${ }^{14-16}$.

The incidence of gastric ulcer in the omeoprazole group was much lower when compared with the groups extract and control and, even when present, the gastric lesions showed minor magnitude and were accompanied by the characteristics of reestablishment and minor tissue activity. The effects of the omeoprazole, used for the treatment of gastritis, peptic ulcers and esophagitis are derived from the reduction of the gastric reduction by means of its high selectivity action in the inhibition of the protons bomb in the parietal cells, not interfering in the acetylcholine or histamine. In this way, it leads to small changes in the gastric succus, in the pepsin secretion and, intrinsic fact, without interfering in the gastric motility. The omeoprazole is more efficient, presents a better cost/benefit rate in the treatment of gastric and duodenal ulcers and was chosen for this study because it is preferable for the treatment of ulcers combine with AINEs ${ }^{11,17}$.

In the group treated with the Sedum dendroideum extract, the presence of erosive lesions was remarkable, becoming evident that there was no reduction in the incidence of gastritis when compared with the control group, which had received only distilled water. A similar experiment, which also intended to evaluate the plant effect on the gastric protection, emphasized the necessity of considering variables such as individual susceptibility of each animal to the diverse conditions to which they were subjected during the experiment. The same study attributed to the high volume administrated the probable effects in the acceleration of the gastric transit in the animals, which could have reduced the action time of the preparation ${ }^{10}$.

There are no well-established parameters for the dose, concentration or posology for the administration of the Sedum dendroideum extract. As it is a succulent plant, with high hydric contents it must be taken into account that the hyper dilution of the extract obtained must be questioned for the impossibility of not reaching its therapeutical dose ${ }^{10}$.

The experiment model for the induction of gastric lesions is too acute and does not perfectly simulates the chronic conditions that culminate with the apparition of gastritis, nor it takes into account the many factors involved in the genesis of the gastro duodenal ulcer that are not the use of AINEs. The administration of balsam, in chronic form, during a longer experimental period could also better contribute for a better observation of its real activity on the gastric mucosa.
The qualitative analysis of the tissues has yet suggested worsening in the gastritis by means of treatment with extract. There were no quantitative significance in the difference of the foci of gastritis found in the control and extract groups, although the lesions presented a major severity and major inflammatory activity in the group treated with the Sedum dendroideum extract, highlighting the importance of the micro analysis in relation to the macro analysis in this study ${ }^{11}$.

As it has been demonstrated, Sedum dendroideum, contains polysaccharide with anti-inflammatory action, tannin, triterpenoids with hepatoprotective activity, alkaloids, piperidines and pirrolidinics and the findings of this study, although surprising, are compatible with another analysis demonstrating the analgesic and anti-inflammatory properties of the extract of a plant, of similar properties, by means of the intra-peritoneal administration of its extract, when compared to the oral administration of indomethacin after the application of inflammatory and algesical stimuli in animals. By means of the same, it was concluded that the plant can be responsible for the inhibition of many chemical mediators, including prostaglandins, which justifies the use of traditional medicine practitioners for the treatment of pain and inflammation and, at the same time, its possible damaging effects on the gastric mucosa ${ }^{7,18}$.

New studies are necessary to evaluate the potential of balsam to cause erosive lesions or even investigate the possible causing gastritis potential of the association of the extract with anti-inflammatory drugs.

\section{Conclusion}

Sedum dendroideum extract did not produce reduction in the erosive gastritis process. As expected, the treatment with omeoprazole produced a major reduction, when compared with the control group.

\section{References}

1. Carvalho CA, Fernandes KM, Matta SLP, Silva MB, Oliveira LL, Fonseca CC. Evaluation of antiulcerogenic activity of aqueous extract of Brassica oleracea var. capitata (cabbage) on wistar rat gastric ulceration. Arq Gastroenterol. 2011;48(4):276-82.

2. Siqueira JS, Lima PSS, Barreto AS, Quintans-Júnior LJ. Aspectos gerais nas infecções por Helicobacter pylori - revisão. RBAC. 2007;39(1):9-13.

3. Huang JQ, Sridhar S, Hunt RH. Role of Helicobacter pylori infection and non-steroidal anti-inflammatory drugs in peptic-ulcer disease: a meta-analysis. Lancet. 2002;359:14-22.

4. Casali JJ, Franzon O, Kruel NF, Neves BD. Análise epidemiológica e emprego do teste rápido da urease em pacientes com úlcera péptica perfurada. Rev Col Bras. Cir. 2012;39(2):93-8. 
5. Saul C, Teixeira CR, Pereira-Lima JC, Torresini RJS. Redução da prevalência de úlcera duodenal: um estudo brasileiro (análise retrospectiva na última década: 1996-2005). Arq Gastroenterol. 2007;44(4):320-4.

6. Tomazzoni MI, Negrelle RRB, Centa ML. Fitoterapia popular: a busca instrumental enquanto prática terapêutica. Texto Contexto Enferm. 2006;15(1):115-21.

7. Duarte MR, Zaneti CC. Morfoanatomia de folhas de bálsamo: Sedum dendroideum Moc. et Sessé ex DC, Crassulaceae. LectaUSF. 2002;20(2):153-60.

8. Bregagnollo EA, Okoshi K, Bregagnollo IF, Padovani CR, Okoshi MP, Cicogna AC. Efeitos da inibição prolongada da enzima de conversão da angiotensina sobre as características morfológicas e funcionais da hipertrofia ventricular esquerda em ratos com sobrecarga pressórica persistente. Arq Bras Cardiol. 2005;84(3):225-32.

9. Watanabe ALC, Watanabe LM. Efeitos do Tenoxicam sobre a cicatrização da parede abdominal: estudo experimental em ratos. Acta Cir Bras. 2005;20(2):12-21.

10. Macaubas CIP, Oliveira MGM, Formigoni MLOS, Silveira Filho NS, Carlini EA. Estudo da eventual ação antiúlcera gástrica do bálsamo (sedum sp), folha-da-fortuna (Bryophyllum calycinum), couve (Brassica oleraceae) e da espinheira-santa (Maytenus ilicifolia) em ratos. Estudo de ação antiúlcera gástrica de plantas brasileiras (Maytenus ilicifolia "Espinheira-santa" e outras). Central de Medicamentos-CEME, Ministério da Saúde; 1988. p.5-20.

11. Aydinli B, Yildirgan MI, Ozturk G, Atamanalap SS, Polat KY, Basoglu M, Gundogdu C, Suleyman H, Kiziltunc A, Gursan N, Oren $\mathrm{D}$. The role of sildenafil citrate in the protection of gastric mucosa from nonsteroidal anti-inflammatory drug-induced damage. Ulus Travma Acil Cerrahi Derg. 2007;13(4):268-73.

12. Oliveira AS, Kersul AP, Prado JP, Oliveira JA, Romão MOC, Terra FS, Costa AMDD, Garcia JAD, Soares EA. Efeitos do alcoolismo crônico na morfologia renal de ratos Wistar. Rev Bras Clin Med. 2011;9(1):46-9.

13. Carlini EA, Duarte-Almeida JM, Rodrigues E, Tabach R. Antiulcer effect of the pepper trees Schinus terebinthifolius Raddi (aroeirada-praia) and Myracrodruon urundeuva Allemão, Anacardiaceae (aroeira-do-sertão). Braz J Pharmacogn. 2010;20(2):140-6.

14. Dias LFT, Melo ES, Hernandes LS, Bacchi EM. Atividades antiúlcera e antioxidante Baccharis trimera (Less) DC (Asteraceae) Rev Bras Farmacogn. 2009;19(1B):309-14.

15. Silvério MS, Sousa OV, Del-Vechio-Vieira G, Miranda MA, Matheus FC, Kaplan MAC. Propriedades farmacológicas do extrato etanólico de Eremanthus erythropappus (DC.) McLeisch (Asteraceae). Rev Bras Farmacogn. 2008;18(3):430-5.
16. Süleyman H, Altýnkaynak K, Göçer F, Ahmet Maras A, Akçay F, Onuk MD, Gepdiremen A. Effect of nimesulide on the indomethacin- and ibuprofen-induced ulcer in rat gastric tissue. Pol J Pharmacol. 2002;54:255-9.

17. Cavallini ME, Andreollo NA, Metze K, Araújo MR. Omeprazole and misoprostol for preventing gastric mucosa effects caused by indomethacin and celecoxib in rats. Acta Cir Bras. 2006;21(3):168-76.

18. Amabeoku GJ, Green I, Kabatende J. Anticonvulsant activity of Cotyledon orbiculata L. (Crassulaceae) leaf extract in mice. J Ethnopharmacol. 2007;112(1):101-7.

\section{Acknowledgements}

To Liliana Auxiliadora Avelar Pereira Pasin by the identification and cataloging of plant species used in this study and Walquiria Costa de Oliveira responsible for English language version.

\section{Correspondence:}

Nilo César do Vale Baracho

Associação de Integração Social de Itajubá

Avenida Renó Junior, 368

37502-138 Itajubá - MG Brasil

Tel.: (55 35)3629-8700

nilocvbaracho@yahoo.com.br

Received: Sept 23, 2013

Review: Nov 21, 2013

Accepted: Dec 20, 2013

Conflict of interest: none

Financial sources: Development Program of Undergraduate Research, School of Medicine Itajuba (PDIC-FMIt) and Minas Gerais Research Foundation (FAPEMIG)

${ }^{1}$ Research performed at Pharmacology, Biochemistry and Pathology Laboratories, Medical School of Itajuba (FMIt), Itajuba-MG, Brazil. 